\title{
Research on the Course Reform of Structure Analysis Based on Practice Project
}

\author{
${ }^{1}$ Zhe Liu \\ ${ }^{1}$ Department of Civil Engineering \\ Shantou University, Daxue Road, NO.243 \\ Shantou, Guang dong Province, P.R.China \\ liuzhe@stu.edu.cn
}

\begin{abstract}
Structural analysis is very important in the learning and education of civil engineering students as a basic course, with the introduction of CDIO education theory and the further reform of excellent engineer. How to make sure this course reach the present requirement becomes a thinking problem to the teachers and students from civil engineering subject. This paper is based on the reform of basic engineering course in Shantou university, and the application of practice project in current structure analysis is discussed, and some suggestions are provided for some related course reform in the future
\end{abstract}

Keywords-CDIO; structure mechanics; civil engineering; practice project

\section{INTRODUCTION}

The concept of CDIO is proposed by MIT and Royal Engineering institute of Sweden after 4 years investigation, which includes the concept of Conceive, Design, Implement and Operate [1]. And this concept is based on the product life cycle from production research to product operating, maintaining and abandoning and then the self-supporting and connecting course system is created, from which the students can study and practice by themselves. This concept is based on the theory and concentrated on practice and emphasizes the core belief of new generation engineers.

The researchers from China applied the CDIO concept into different subjects, such as information engineering [2] etc, from which the excellent engineer project of Chinese engineers has been created, at the same time the concept has been input into the detailed course outline, such as civil engineering material[3], engineering economics [4] and engineering management [5]. Although the above courses had been investigated based on CDIO concept from different subjects or courses, the investigation on the reform of structural analysis has been rare. And civil engineering subject is a strong practice and project-based one, which match the CDIO theory, Shantou university develops the CDIO concept and proposed EIP-CDIO theory, and many courses reform of Shantou university are based on this theory. In this paper the reform based on basic course of structural analysis from civil engineering subject is selected as the target, and the deep discussion was done based on the project design, and the application in this project considering the CDIO concept is also discussed. The consulting of theory and practice based on this paper will be used in the future for the people who will do the engineering or civil engineering education reform .

\section{STRUCTURAL ANALYSIS COURSE STATUS}

Wherever Times is specified, Times Roman or Times New Roman may be used. If neither is available on your word processor, please use the font closest in appearance to Times. Avoid using bit-mapped fonts if possible. True-Type 1 or Open Type fonts are preferred. Please embed symbol fonts, as well, for math, etc.

The traditional course outline design is the following procedure, which is the mode of teaching, homework, exam, but after many years investigation on the teaching process and study outcome, it is found that this kind of mode only cultivate the ability of doing homework, not the ability of solving the real engineering projects using the basic mechanics course, while it is very important to the civil engineering graduate, so a new engineering education reform named as EIP-CDIO has been proposed by Shantou university, the structural analysis course group design some engineering projects based the above theory, which attract much more interests from students in the process of Conceiving, Designing and Implementing, which excited the interests of students actively and understand the basic concept and method of structural analysis and also the application in the engineering projects.

\section{A. Status of Structural Analysis In Current Course System}

Structure Analysis plays a very important role in the internal and external education system of civil engineering, as a basic mechanic's course, which is based on the advanced mathematics, theoretical mechanics, material mechanics in one sider, on the other hand which is also a basic course for the course of steel structure, concrete structure, soil mechanics and foundation, structural seismic engineering, this course provides necessary basic structural mechanics and calculating approach for the structures, and also is very useful in the final year project design, this course is located at the position connecting the up and bottom courses, the learning outcome will influence the final results of above courses and also is one of important factors for the graduate quality .

\section{B. Key and Important Points}

In this course, the small elastic deformation is assumed and the real structure is simplified and calculation diagram is created, using the balance condition, force method, displacement method to analyze the internal force, deformation, dynamic characteristics and stability of structure. Besides large volume exercise and course work, it is very important to connect the theory with the real structure for this course 
understanding, which is the procedure: real structure $\rightarrow$ calculation diagram $\rightarrow$ approach selecting $\rightarrow$ analysis $\rightarrow$ results checking, and the above procedure is the classical mechanics method, computational structural mechanics and concept structure mechanics (Fig.1), at the same time the application of these approaches has the same idea as the project-based concept proposed by the CDIO theory.

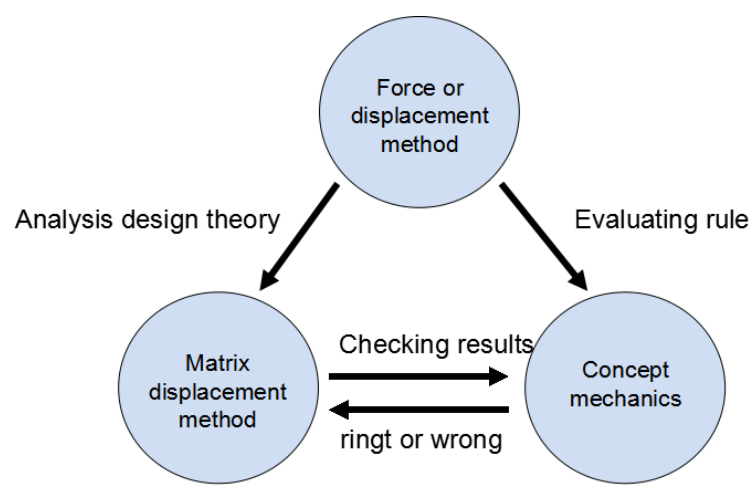

FIGURE I. RELATIOSHIP OF THREE KINDS OF MECHANICS

\section{PRACTICE PROJECT APPLICATION IN THE COURSE OF STRUCTURAL ANALYSIS}

\section{A. Project Design}

Table I lists the project name, technical object, ability object, requirement and evaluation approach of structure analysis.

\section{TABLE I. PROJECT OBJECTIVES}

\begin{tabular}{|c|c|}
\hline Project name & Matrix displacement calculation \\
\hline Technical Object & $\begin{array}{l}\text { - Learn the basic theory of Matrix displacement } \\
\text { method } \\
\text { - Coordinate transform and stiffness matrix } \\
\text { assembling } \\
\text { - Understanding the procedure of program and } \\
\text { analysis software }\end{array}$ \\
\hline Ability Object & $\begin{array}{l}\text { - Ability of deciding and analyzing general } \\
\text { engineering problems } \\
\text { - Problem find, solving and discussing } \\
\text { - Communicating and presenting the project } \\
\text { design using language, writing, graphic and } \\
\text { calculation }\end{array}$ \\
\hline Requirement & $\begin{array}{l}\text { - Doing matrix analysis using Excel } \\
\text { - Checking results by Sap2000 }\end{array}$ \\
\hline Evaluation & - Presentation \\
\hline
\end{tabular}

\section{B. Problems Reflection}

Being different from the projects of traditional structure analysis course, the project and course based on the CDIO concept needs to consider the ability of students and learning outcome and reflection and summary of knowledge, Table II lists the ability and problem reflection of one project
TABLE II. CDIO ABILITY AND PROJECT PROBLEM REFLECTION

\begin{tabular}{|c|c|}
\hline Stage & Reelection and $\mathrm{CDIO}$ ability \\
\hline $\begin{array}{l}\text { Preparation } \\
\text { stage }\end{array}$ & $\begin{array}{l}\text { - Objective : listing key problem and difficulties and } \\
\text { conditions } \\
\text { - The difference of pulling and compressing failure, the } \\
\text { mainly controlled or un-controlled factors } \\
\text { - Considering these factors in the project } \\
\text { - Considering these factors in the results (CDIO 2.2 ) } \\
\text { - How to reduce the influence on the results form the } \\
\text { uncertain factors (CDIO 2.1.3) } \\
\text { - Wide application of experimental results } \\
\text { Report requirement: } \\
\text { 1. Experiment objective } \\
\text { 2. Experiment design (CDIO 2.1.1 and CDIO 2.3) } \\
\text { 3. Predicting Results (CDIO 2.1.3) } \\
\text { 4. Experimental process (CDIO 2.2) } \\
\text { 5. Data processing (CDIO2.2.3) } \\
\text { 6. Data analyzing (CDIO 2.2.4) } \\
\text { 7. Reliability analysis (CDIO 2.2.4) } \\
\text { 8. Results expression (CDIO 2.2 and CDIO 3.2) }\end{array}$ \\
\hline $\begin{array}{c}\text { Design and } \\
\text { competition } \\
\text { stage }\end{array}$ & $\begin{array}{l}\text { - The objective of this project and basic requirement } \\
\text { - Different structures proposed (CDIO 4.1.1) } \\
\text { - The final design of group (CDIO } 2.4 \text { and CDIO } 3.1 \text { and } \\
\text { CDIO 3.2) } \\
\text { - Calculating diagram and results (CDIO 2.1.2) } \\
\text { - The process of simplifying the structure from 3D to 2D } \\
\text { and the difference between the calculating diagram and the } \\
\text { real structure (CDIO 2.1.3) } \\
\text { - How to reach the requirement and how to prepare this } \\
\text { project (CDIO 2.1.4) } \\
\text { - The design failure load and mechanism and the cause of it } \\
\text { (CDIO2.1.5) }\end{array}$ \\
\hline Prestation & $\begin{array}{l}\text { - 5mins presentation, presenting the important learning and } \\
\text { understanding in this project }\end{array}$ \\
\hline
\end{tabular}

\section{Grades}

In this part, the design project of matrix displacement analysis of structural analysis is taken as an example, and the score breakdown is composed by the following part:

Total score $=$ Design process $(30 \%)+$ Software level $(30 \%)+$ Design and analysis report $(40 \%)$

TABLE III. PROJECT SCORE STANDARD

\begin{tabular}{|c|c|c|c|c|c|}
\hline Score standard & $\begin{array}{c}0 \\
\text { bad }\end{array}$ & $\begin{array}{c}1 \\
\text { weak }\end{array}$ & $\begin{array}{c}2 \\
\operatorname{good}\end{array}$ & $\begin{array}{c}3 \\
\text { excellent }\end{array}$ & $\begin{array}{c}4 \\
\text { Distinguished }\end{array}$ \\
\hline $\begin{array}{l}\text { Compiling the code } \\
\text { based on the requirement } \\
\text { of project content and } \\
\text { doing analysis }(20 \mathrm{p})\end{array}$ & & & & & \\
\hline $\begin{array}{l}\text { Discuss the effects of } \\
\text { parameter varying on the } \\
\text { analysis results }(20 p)\end{array}$ & & & & & \\
\hline $\begin{array}{l}\text { Preparing the design } \\
\text { project and operating } \\
\text { alone and finding and } \\
\text { solving and discussing } \\
\text { the problems }(10 \mathrm{p})\end{array}$ & & & & & \\
\hline $\begin{array}{l}\text { Using the commercial } \\
\text { code to evaluate the final } \\
\text { results }(30 \mathrm{p})\end{array}$ & & & & & \\
\hline $\begin{array}{l}\text { Writing report and data } \\
\text { analyzing based the } \\
\text { results and summarizing } \\
(20 \mathrm{p})\end{array}$ & & & & & \\
\hline
\end{tabular}




\section{Relationship Between Project and Ability}

Table IV lists the learning level and project training contribution on the CDIO ability, which creates the connection between the education approach and personal ability.

TABLE IV. PROJECT AND CDIO ABILITY

\begin{tabular}{|c|c|c|c|}
\hline \multicolumn{2}{|c|}{ CDIO Ability } & \multirow{2}{*}{$\frac{\text { Level }}{3}$} & \multirow{2}{*}{$\begin{array}{r}\text { Pro } \\
0\end{array}$} \\
\hline \multirow{4}{*}{$\begin{array}{l}\text { 1.Technical } \\
\text { knowledge and } \\
\text { problem solving }\end{array}$} & 1.1 Mathematics & & \\
\hline & 1.2 Natural sciences & 2 & ○ \\
\hline & 1.3 Materials science & 2 & 0 \\
\hline & 1.4 Mechanics & 3 & 0 \\
\hline \multirow{5}{*}{$\begin{array}{l}\text { 2. Personal ability } \\
\text { and professional } \\
\text { ability and } \\
\text { attitudes }\end{array}$} & $\begin{array}{l}\text { 2.2 Experiment and knowledge } \\
\text { finding }\end{array}$ & 2 & O \\
\hline & 2.1 Problem recognition and solving & 3 & 0 \\
\hline & 2.1.4 Uncertain analysis & & 0 \\
\hline & 2.4 Personal ability and Attitudes & 2 & \\
\hline & 2.4.6 Lifelong learning & 2 & 0 \\
\hline \multirow{3}{*}{ 3.Communication } & 3.1Team work & 2 & 0 \\
\hline & 3.1.4 Leadership & 2 & 0 \\
\hline & 3.2 Communication & 3 & 0 \\
\hline \multirow{2}{*}{$\begin{array}{l}\text { 4. Conceiving, } \\
\text { Designing, } \\
\text { Implementing and } \\
\text { Operating system } \\
\text { in enterprises }\end{array}$} & 4.4 Design & 4 & $\bullet$ \\
\hline & $\begin{array}{l}4.3 \text { Setup objectives and requirement } \\
\text { of system }\end{array}$ & 2 & ○ \\
\hline
\end{tabular}

\section{E. MYSTU Platform}

MYSTU education platform is a one to communicate and learn for students and teachers (Fig.3), including course outline, students discussing zone, course work managing, course managing etc, the teachers can post and arrange course work or home work on it and also check them and record the score, which realize the function of electronizing and recording.

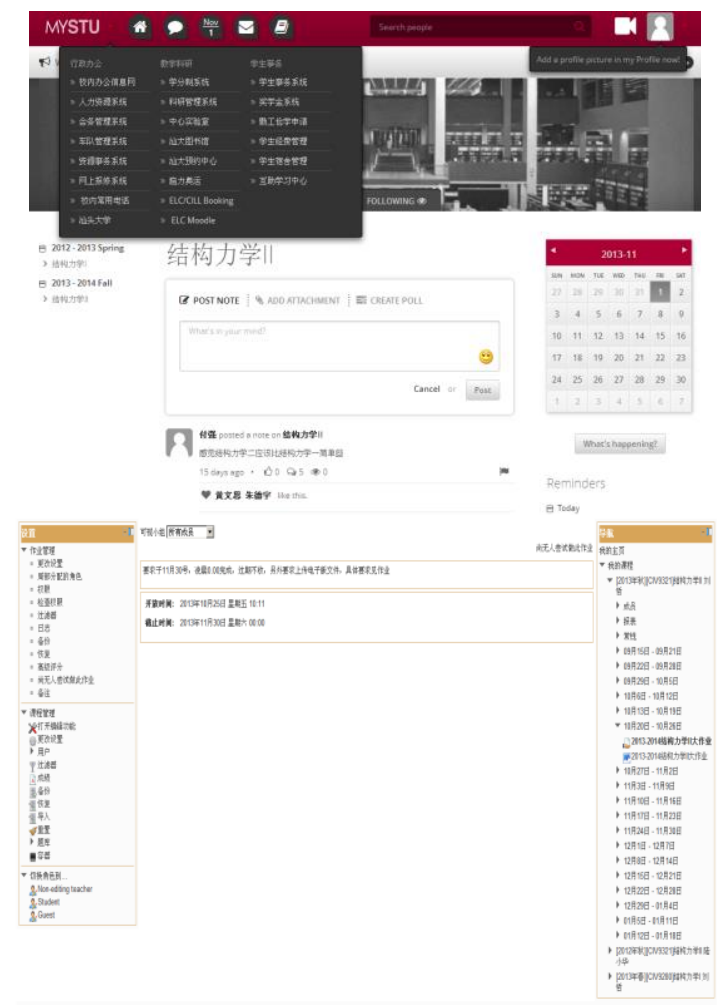

FIGURE II. MYSTU OPERATING PLATFORM

After reforming the structure analysis based on the CDIO concept, the students can submit and ask questions from this platform, which really connects the class study with web study, which realize the communication between the students and teachers on time and also avoid the later submitting course work.

\section{PRePare Your PAPER Before Styling}

It is very important for the learn outcome to evaluate the value of one course, that how to evaluate the reform results of CDIO theory in the project of structure analysis becomes a standard, Fig.3 plots the project process, such as paper-based model creation, calculation diagram and load test of such model, while the students are divided into different group including 5-6 guys, after finishing the projects these students will present the final results and the grade will depend on Table III.

The presentation will cultivate the ability of expression and organization of students, and help the students to learn and understand the structural concept and its application in real structure deeply. And this process cultivate the students ability of understanding, asking and learning in nature. 


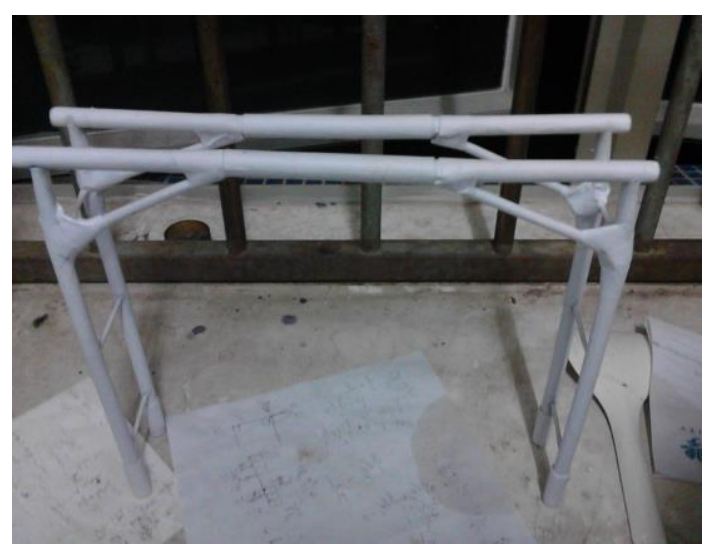

(a) Paper-based structure

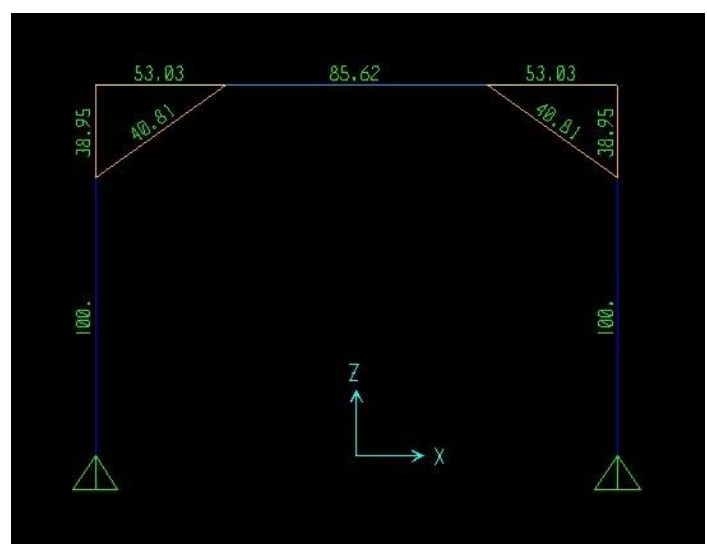

(b) Calculation diagram of matrix displacement method

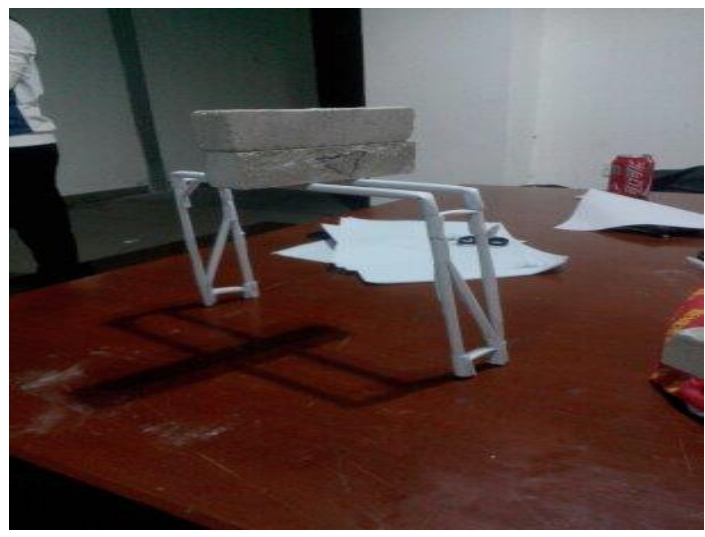

(c) Load test

FIGURE III. PROJECT PROCESS

\section{CONCLUSIONS}

CDIO engineering education mode is a complete system created based on the requirement of engineering field, which answers the questions such as "what kind of graduate we need " and how to teach the students asked by the engineering field. This paper proposes the EIP-CDIO reforming concept and theory in Shantou university based on the course of structure analysis and also proposes a project-based teaching mode of structure analysis, based on the reforming it can be found that after introducing the practice project and EIP-CDIO education mode, the students enthusiasm and active study are stimulated and the structure analysis attracts much more attention of students than before

\section{ACKNOWLEDGMENT}

This research was supported by the research program funded by reform research program of Shantou university

\section{REFERENCES}

[1] Peihua Gu, "CDIO in China", Higher Education Research, vol. 01, pp. $24-40,2008$

[2] Chaoyang He,"On the eleactronic and information engineering personel traing based on C\&P-CDIO mode", Higher Education Research, vol.2, pp.60-63, 2013

[3] Huifan Chen, "Application research on materials of civil engineering based on CDIO mode, Journal of architectural education in institutions of higher learning, vol.20, pp.39-43, 2011

[4] Guomai Liu, Teaching reform of engineering economics course with CDIO, Journal of architectural education in institutions of higher learning, vol.21, pp.64-67, 2012

[5] Zhizhao Feng, Exploration into the CDIO- based practice base construction Mode of engineering management, Higher Education Research, vol.04, pp.165-170, 2012 